\title{
DIVERSITY OF BEES AT DIFFERENT ALTITUDES IN THE KNUCKLES FOREST RESERVE
}

\author{
W.A.I.P. Karunaratne* and J.P. Edirisinghe \\ Department of Zoology, Faculty of Science, University of Peradeniya, Sri Lanka. \\ Accepted 14 May 2008
}

\begin{abstract}
A year around survey of bees carried out in the Knuckles mountain range at different altitudes having specific habitat types highlighted the effect of altitude and habitat on the presence and abundance of bees. The study was based on hourly counts of bees made once every month in five selected habitats; natural forest, managed cardamom, Patana grassland, cultivated home gardens and mixture of habitats including home gardens, scrublands and rice fields, situated at different altitudes ranging from $150-1350 \mathrm{~m}$. The study recorded a total of 62 bee species belonging to 26 genera in 4 families representing more than $3 / 4$ of the total bee fauna recorded for Sri Lanka.

The distribution of bee species decreased with increasing elevation. Areas under cardamom cultivation harboured the lowest number of bee species. Shannon diversity index gave the highest score for the bee diversity in home gardens. The finding of this study highlights the fact that the highest diversity of bees is at lower elevations where the climate is comparatively warmer. Furthermore, at lower elevations due to human settlements, the vegetation comprises a mixture of cultivated crops, flowering herbs and patches of natural vegetation providing a ready source of pollen and nectar for bees throughout the year.
\end{abstract}

Key Words: Knuckles Forest Reserve, bees, altitude, climate, vegetation

\section{INTRODUCTION}

The climate, which is a reflection of the altitude and latitude plays an important role in the distribution of plants and animals in the world and is the rule for insects in general and for bees in particular. The diversity of bees at different altitudes in the tropics may provide clues to the likely responses of bee species and communities to climate change at any one point over time.

The Knuckles mountain range situated in the Intermediate zone of the island is an aggregation of unique and spectacular peaks in the most northern and northeastern outlier of the central mountain massif of Sri Lanka from which it is separated by the Dumbara valley. Along this valley runs the River Mahaweli, the longest river in Sri Lanka. Mountain slopes of the west and southwest have a submontane ever wet climate while the east and the north east are seasonally dry. The peaks are frequently covered with mist. They have a montane ever-wet climate and are subjected to strong winds year around.

The Knuckles range has a rich floristic composition comprises 1033 species of flowering plants of which 160 (15\%) are endemic to Sri Lanka (Bambaradeniya and Ekanayake, 2003). These provide an attractive source of nectar and pollen particularly for bees that may play an important role in the maintenance of the flora through pollination.

The Knuckles range encompasses a land area of 21,000 ha within an altitude of 115-1906 m. The different climatic zones and the latitudinal range have given rise to a variety of vegetation types namely; montane (>1300 m), sub-montane (1300-600m) and lowland semi-evergreen (<700m) (Bambaradeniya and Ekanayake, 2003). Human settlements, especially in the lowland have given rise to a variety of man-made habitats due to different land use patterns practiced by the villagers.

The study examines the composition and diversity of bees in an altitudinal gradient along the eastern and northern slopes of the Knuckles reserve with different climatic zones and comprising a variety of natural and man-made habitats.

\section{METHODS}

Study area

The study area encompasses the eastern and northern boundary of the Knuckles range, in

*Corresponding author’s email: inokap@pdn.ac.lk 
proximity to the Rattota - Pallegama road that runs through the Knuckles reserve. Five study sites were selected (Fig. 1) at different altitudes ranging from $455-1350 \mathrm{~m}$ based on the climate and vegetation type to represent 5 different habitats (Plate 1). Table 1 gives the location, altitude, climatic zone, and the vegetation type of the 5 study sites. The sampling area in each of the habitat was approximately 1 ha. in extent.

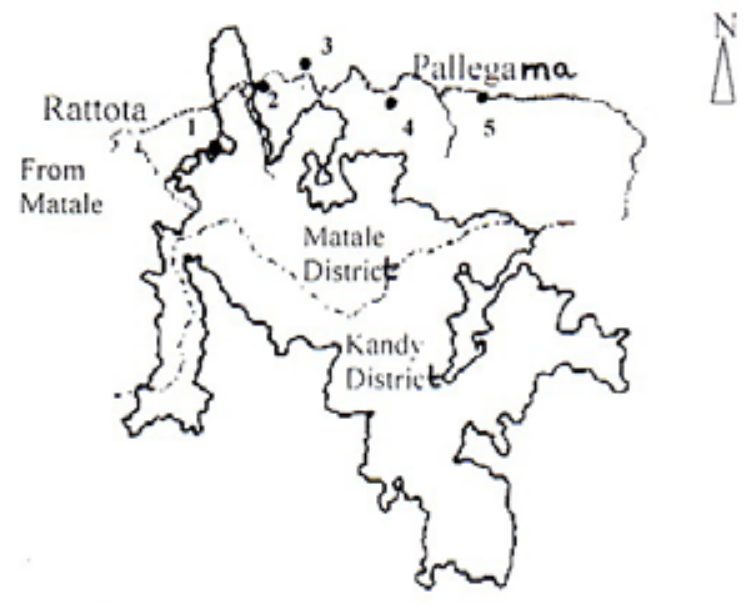

Figure 1. Map of the Knuckles Forest Reserve showing the road along which the 5 study sites were located.

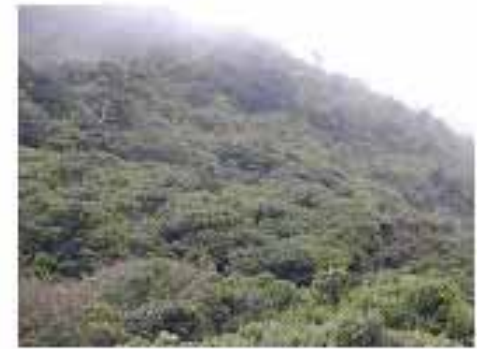

Site 1 Natural forest

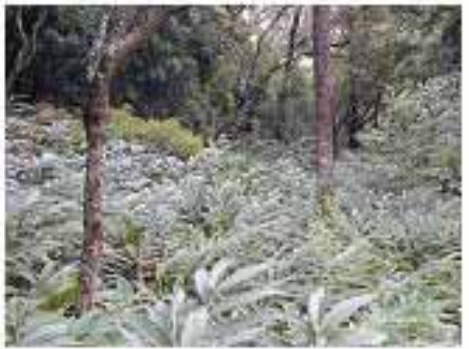

Site 2 Managed cardamom

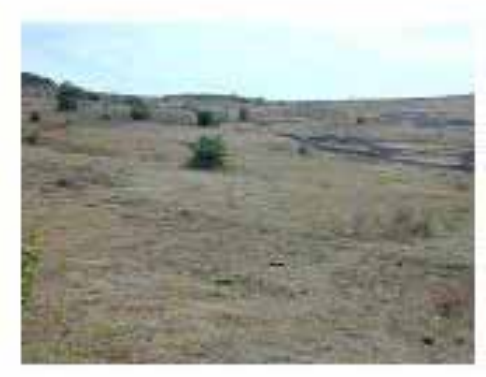

Site 3 Patana grassland

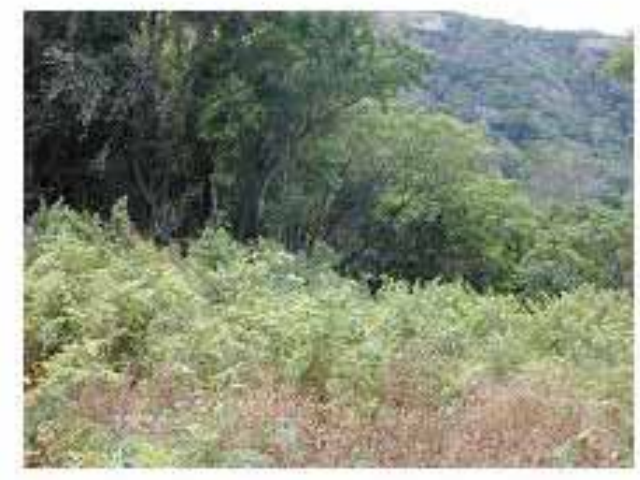

Site 4 cultivated home garders

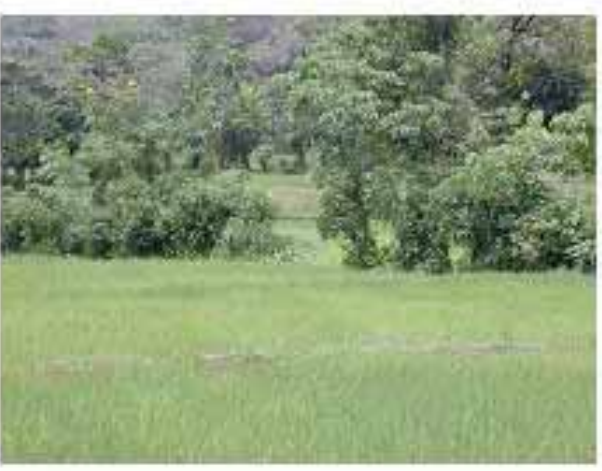

Site 5 rice fields and scrubland

Plate 1. Study sites 1-5 located at different altitudes representing the different vegetation types. 
Table 1. Physical and vegetation features of study sites at the Knuckles mountain range.

\begin{tabular}{|c|c|c|c|c|c|}
\hline Study site & Site 1 & Site 2 & Site 3 & Site 4 & Site 5 \\
\hline \multirow[t]{2}{*}{ Location } & N $07^{0} 31.627^{\prime}$ & N 07 $31.332^{\prime}$ & N $07^{0} 32.902^{\prime}$ & N $07^{0} 32.825^{\prime}$ & N 07 $32.633^{\prime}$ \\
\hline & E $080^{\circ} 44.047^{\prime}$ & E $080^{\circ} 44.405^{\prime}$ & E $80^{\circ} 45.133^{\prime}$ & E $080^{\circ} 47.496^{\prime}$ & E $080^{\circ} 48.857^{\prime}$ \\
\hline Altitude (m) & 1350 & 1065 & 840 & 455 & 150 \\
\hline Forest type & Montane & Sub-montane & Sub-montane & Semi-evergreen & Semi-evergreen \\
\hline $\begin{array}{l}\text { Vegetation } \\
\text { type }\end{array}$ & Natural forest & $\begin{array}{l}\text { Managed } \\
\text { cardamom }\end{array}$ & $\begin{array}{l}\text { Patina } \\
\text { grassland }\end{array}$ & $\begin{array}{l}\text { Cultivated home } \\
\text { gardens }\end{array}$ & $\begin{array}{l}\text { Rice fields, home } \\
\text { gardens, scrublands }\end{array}$ \\
\hline Terrain & $\begin{array}{l}\text { Flat with } \\
\text { sloping edges }\end{array}$ & Gradual slope & Almost flat & Almost flat & Flat \\
\hline $\begin{array}{l}\text { Water } \\
\text { availability }\end{array}$ & $\begin{array}{l}\text { Dry soil, no } \\
\text { water available }\end{array}$ & Wet soil & $\begin{array}{l}\text { Seasonal } \\
\text { streams }\end{array}$ & Dry & $\begin{array}{l}\text { Seasonal streams, } \\
\text { rice fields }\end{array}$ \\
\hline Temperature & $15-18^{0} \mathrm{C}$ & $18-20^{\circ} \mathrm{C}$ & $21-25^{0} \mathrm{C}$ & $24-27^{0} \mathrm{C}$ & $25-28^{0} \mathrm{C}$ \\
\hline
\end{tabular}

\section{Climate and Study Period}

The Knuckles Mountain Range forms an effective barrier to both southwest (May-July) and northeast (October-January) monsoons during which it receives most of its rainfall. The eastern and northern parts where the study sites are located are seasonally dry, while the upper parts have a montane ever-wet climate. The annual rainfall in the wettest area is $2725-4470$ $\mathrm{mm}$. The temperatures range between $25-27^{\circ} \mathrm{C}$ at lower altitudes and between $18-20^{\circ} \mathrm{C}$ at higher altitudes. The study was conducted over a period of one year to cover the monsoonal and dry periods of the study area. Field visits were planned in consultation with the villagers in the study area in order to avoid rainy days for conducting sampling for bee.

\section{Sampling method}

The five habitats were visited once every month over a period of one year commencing from January 2003. At each habitat situated at a particular elevation, one hour was spent collecting bees within an area of 1 ha. Bees were collected using a standard sweep net. Bees on vegetation were collected by sweeping the above ground vegetation. Those on flowers and in flight were individually collected using the sweep net. On a given sampling day, bees were collected at a different hour from the 5 sites to cover the activity period of all bee species. As all 5 habitats cannot be sampled at the same time on a given sampling day, the hour of sampling was rotated among the five habitats to include the activity period of bees (9.00 am - $4.00 \mathrm{pm})$. Altogether 40 sampling hours were spent through out the study period making eight hours of colleting at a particular habitat.

Of the bees collected in this manner, the easily identifiable common bees were released on site after making a count and recording their identity. Collected bees were identified, the number of individuals in a given species collected during one hour periods, from each site, on each sampling day was recorded.

\section{Identification of bees}

Bees collected were identified up to family, genera and subgenera using keys of Michener (2000). Species level identification was based on keys and descriptions of Bingham (1897). In addition, revised information on Sri Lankan bee species by Sakagami and Ebmer (1987), Schwarz (1990), Sakagami (1978 \& 1991), Sakagami, Ebmer and Tadauchi (1996 \& 1998) and Baker (1996) were used. Locally available reference specimen collections of bees in the National Museums, Colombo and the Invertebrate Systematics and Diversity Facility (ISDF) in the Department of Zoology, University of Peradeniya were also used to confirm the identity of certain species. The identity of difficult specimens was confirmed by several specialists.

\section{Data analysis}

Based on the number of bee species and their abundance in each site during the 13 month sampling period, bee diversity in each of the study sites was calculated using the Shannon Diversity Index (Magurran, 1998). Comparison of bee diversity between sites was based on the magnitude of the diversity index.

To predict the total number of species in the study encompassing the five study sites, the data on species distribution and abundance was fitted to a truncated lognormal model following Magurran (1988). A species accumulation curve representing the accumulated number of species per unit collecting effort (hours of collecting/person) was constructed. 


\section{RESULTS}

\section{Species composition}

A total of 1694 bee specimens were collected from the 5 sites on 13 sampling days during the 13 months of sampling. These belonged to 62 species, 26 genera and 3 families (Table 2 and Appendix 1). Family Apidae and Halictidae included the largest number of genera and family Apidae included the largest number of species followed by Halictidae (Table 2). Certain genera

\section{Phenology of Bees}

The monthly collection of bees indicated a variation in their occurrence over the 13 month study period (Table 3 ). The three bee specie, Apis cerana, Trigona iridipennis and Ceratina hieroglyphica were encountered throughout the study period. Most other species were collected during few or several months of the year. A few bee species in the genera Nomada, Thyreus, Lasiolgossum, Coelioxys and Megachile were collected only during a single sampling day representing a specific month. The number of bee species collected was highest in the months of February and March and lowest in May and June.

\section{Distribution and Diversity of Bees}

The distribution of bees in the 5 habitats with respect to the 3 climatic zones, vegetation, and altitude is given in Appendix 1 and Fig.2. At the lowest elevation $(150 \mathrm{~m})$ where several habitats (rice fields, home gardens and scrublands) were present, recorded the highest number of bee species (46 spp.). At $455 \mathrm{~m}$, in the cultivated home gardens, 41 species of bees were recorded. In the submontane zone at $840 \mathrm{~m}$ in the Patana grassland 16 bee species were recorded. At the highest elevation $(1350 \mathrm{~m})$ in the montane zone, the natural forest harboured only 10 species of bees. At $1065 \mathrm{~m}$ elevation where a monoculture of cardamom was grown under natural submontane forest cover, only 3 bee species were recorded. of bees were represented by several species; Amegilla (06 spp.), Ceratina (05 spp.), Lasioglossum (07 spp.) and Megachile (06 spp.) (Appendix 1). Among the bees collected were 10 species of parasitic bees belonging to the genera Nomada (2 spp.), Thyreus (4 spp.), Coelioxys (2 spp.) and Euaspis (2 spp.). Bee species recorded from the study area of the Knuckles mountain range are given in Appendix 1, listed under Genera and species.

The bees at Knuckles showed a distinct distribution with respect to altitude in the 5 habitats. As shown in Fig. 2, certain bee genera and species were confined to specific elevations. Thus, 11 bee species and 2 genera were confined to $150 \mathrm{~m}$ altitude and 5 species and 1 genus to $455 \mathrm{~m}$ altitude. At higher elevations only a fewer number of bee species were present and no genera were confined to $>1065 \mathrm{~m}$ altitude.

The species composition of bees in the 5 habitats differed depending on the elevation, natural vegetation or crops cultivated. The common honeybee, Apis cerana was present across the entire elevation gradient, while certain species were restricted in distribution with respect to elevation. Nomada priscilla, Lasioglossum carnifrons, L. alphenum, and $L$. bidentatum in particular were confined to the highest altitude of $1350 \mathrm{~m}$. To the lowest elevation of $150 \mathrm{~m}$, a larger number of bee species (11) the genera, Amegilla (1 sp.), Trigona (1 sp.), Braunsapis (1 sp.), Xylocopa (1 sp.), Ceylalictus (1 sp.), Gnathonomia (2 sp.), Lasioglossum (1 sp.), Coelioxys (1 sp.) and Megachile (2 sp.) were confined (Appendix 1).

Table 2. Taxonomic composition of bees in the 5 study sites of the Knuckles mountain range.

\begin{tabular}{lll}
\hline Family & Genera & Species \\
\hline Apidae & 12 & 30 \\
Halictidae & 12 & 20 \\
Megachilidae & 05 & 12 \\
\hline
\end{tabular}




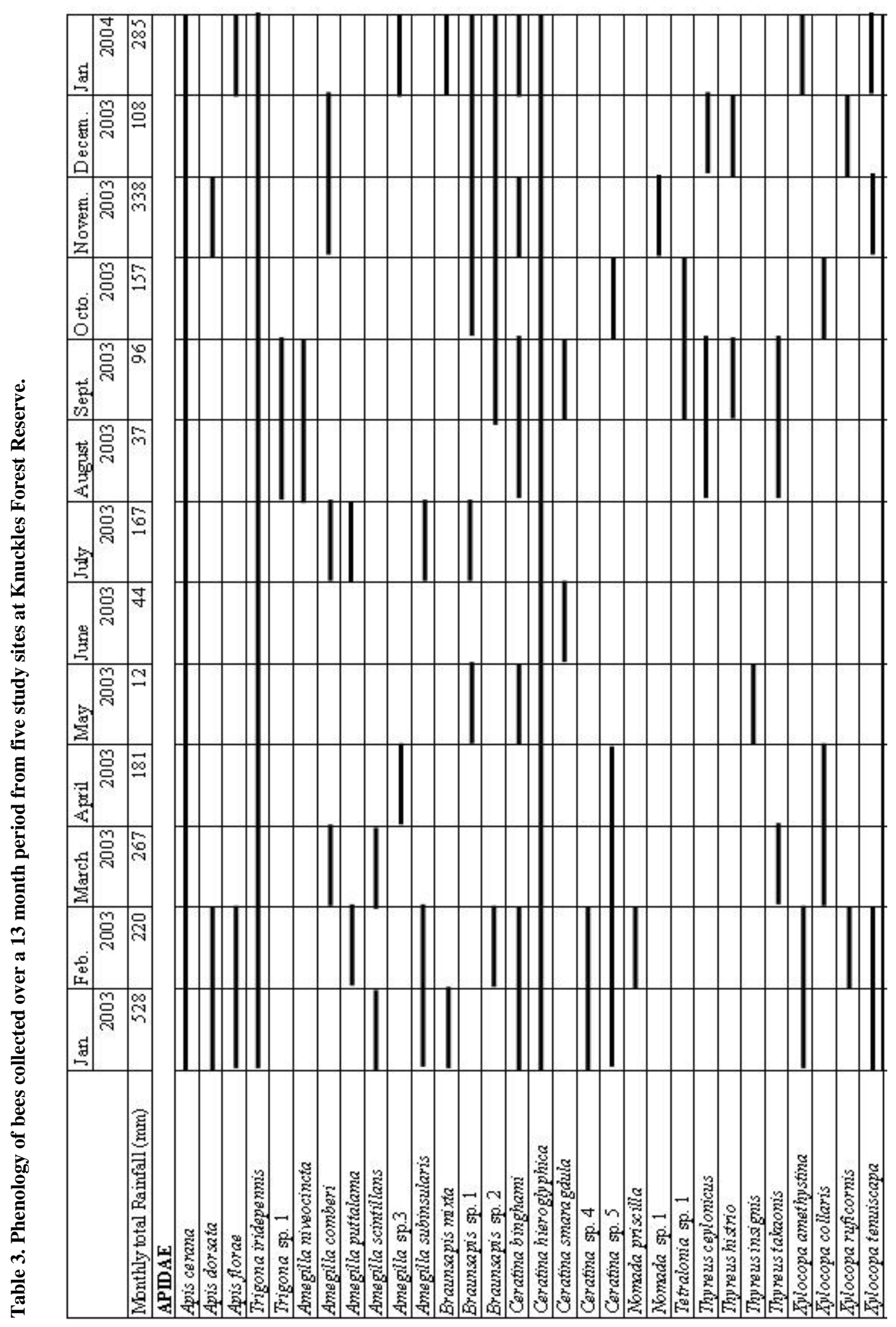




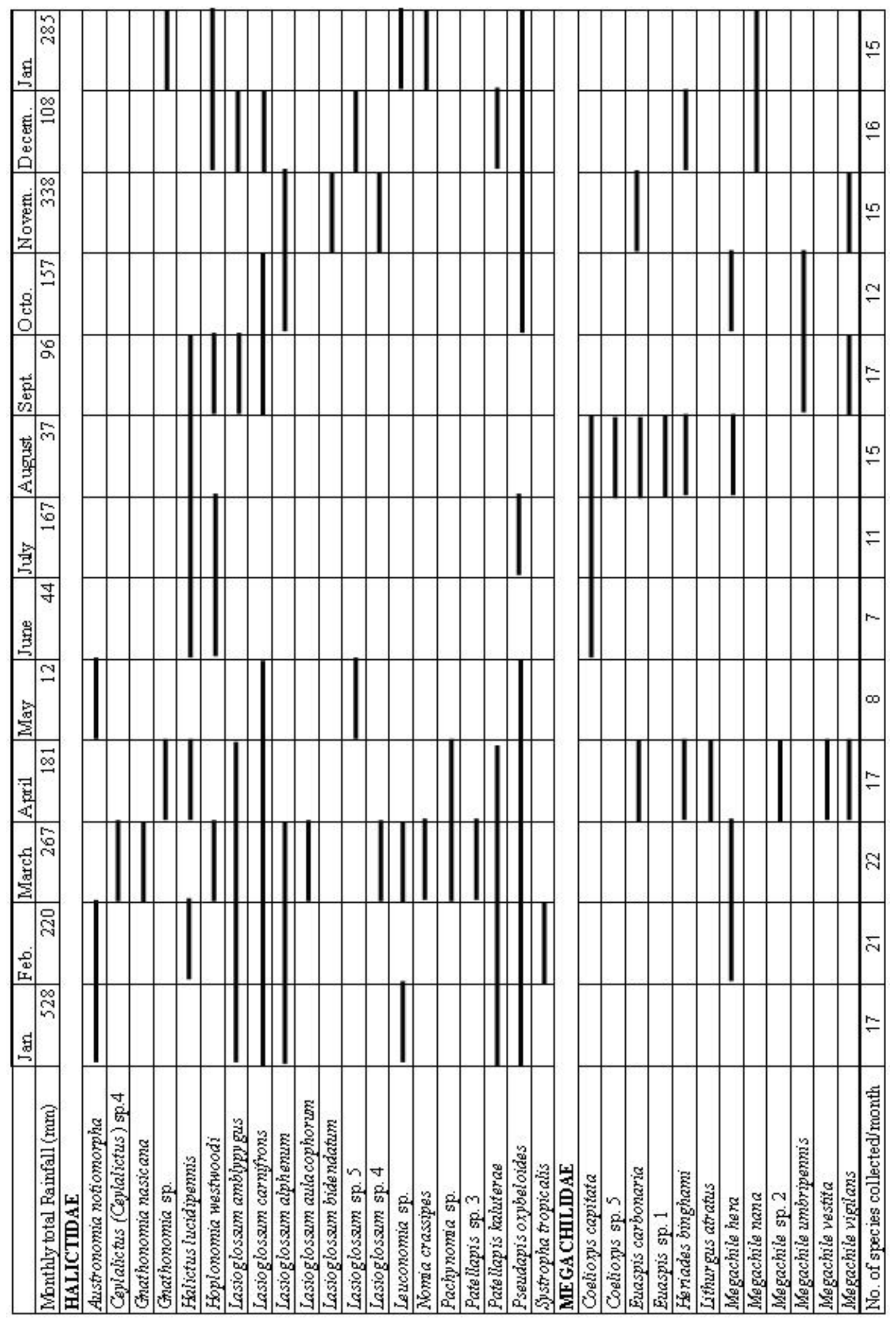




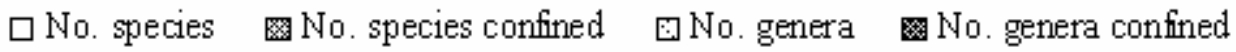

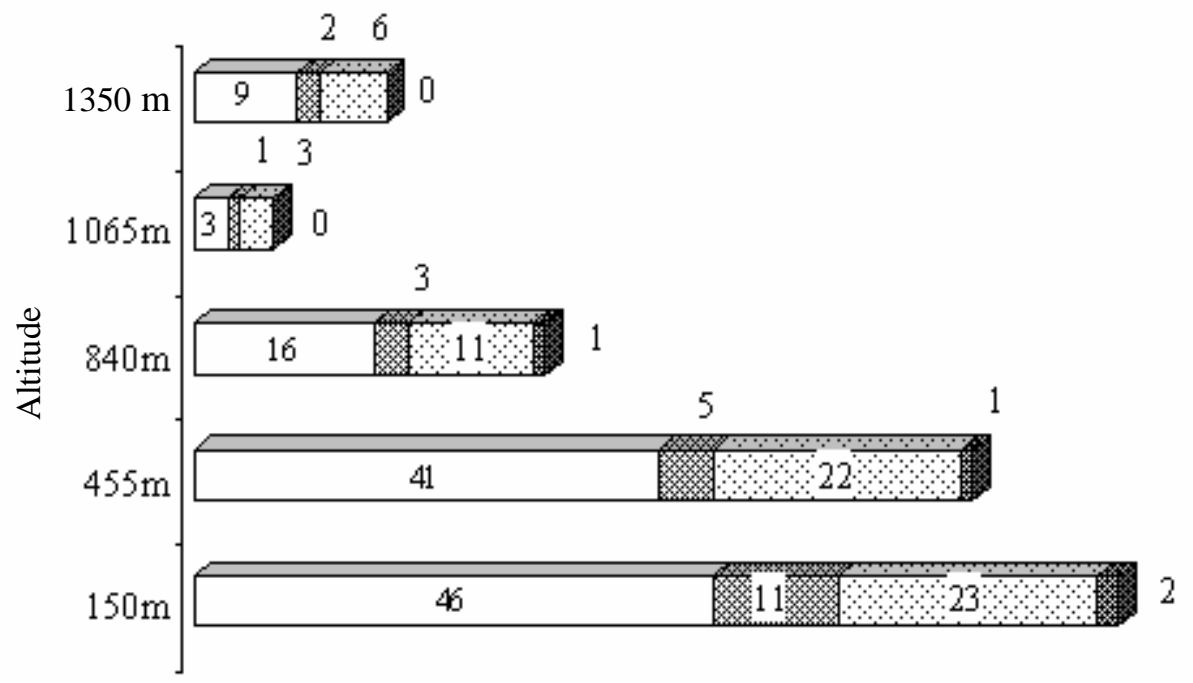

Figure 2. Distribution of bee genera and species in relation to altitude at the Knuckles mountain range.

\section{Bee Diversity Indices}

Hourly sampling of bees during the 13 months in the 5 habitats enabled the comparison of bee diversity. Shannon Diversity Index calculated for the 5 habitats are given in Table 4 . The highest index $\left(\mathrm{H}^{\prime}=2.9005\right)$ was obtained for site 4 (cultivated home gardens) in the semievergreen zone. The second highest diversity index $\left(\mathrm{H}^{\prime}=2.7701\right)$ was for site 5 (comprising rice fields, home gardens and scrub lands) in the same zone. Although sites 3 (Patana grassland) in the submontane zone gave an Index of $\mathrm{H}^{\prime}=$ 2.3171, site 2 (managed cardamom) in the same zone gave a very low index which was lower than that for site 1 (natural forest) in the montane zone.

\section{The Species Accumulation Curve}

Following hourly sampling of bees the cumulative bee counts were plotted into a species accumulation curve (Fig. 3). The curve shows a steady increase with increasing sampling hours and reached a plateau at 35 hours.

To predict the total number of bees in the study area the data set on species abundance was fitted to a Truncated Log-Normal Model as shown in Fig. 4. The expected number of species obtained for the community ( $\left.\mathrm{S}^{*}\right)$ is 64 .

Table 4. Shannon Diversity Index for bees sampled at the 5 study sites of the Knuckles mountain range.

\begin{tabular}{clcc}
\hline Site & Forest type & Altitude $(\mathrm{m})$ & Shannon Diversity Index $\left(H^{\prime}\right)$ \\
1 & Montane & 1350 & 1.5922 \\
2 & Submontane & 1065 & 0.7993 \\
3 & Submontane & 840 & 2.3171 \\
4 & Semi-evergreen & 455 & 2.9005 \\
5 & Semi-evergreen & 150 & 2.7701 \\
\hline
\end{tabular}




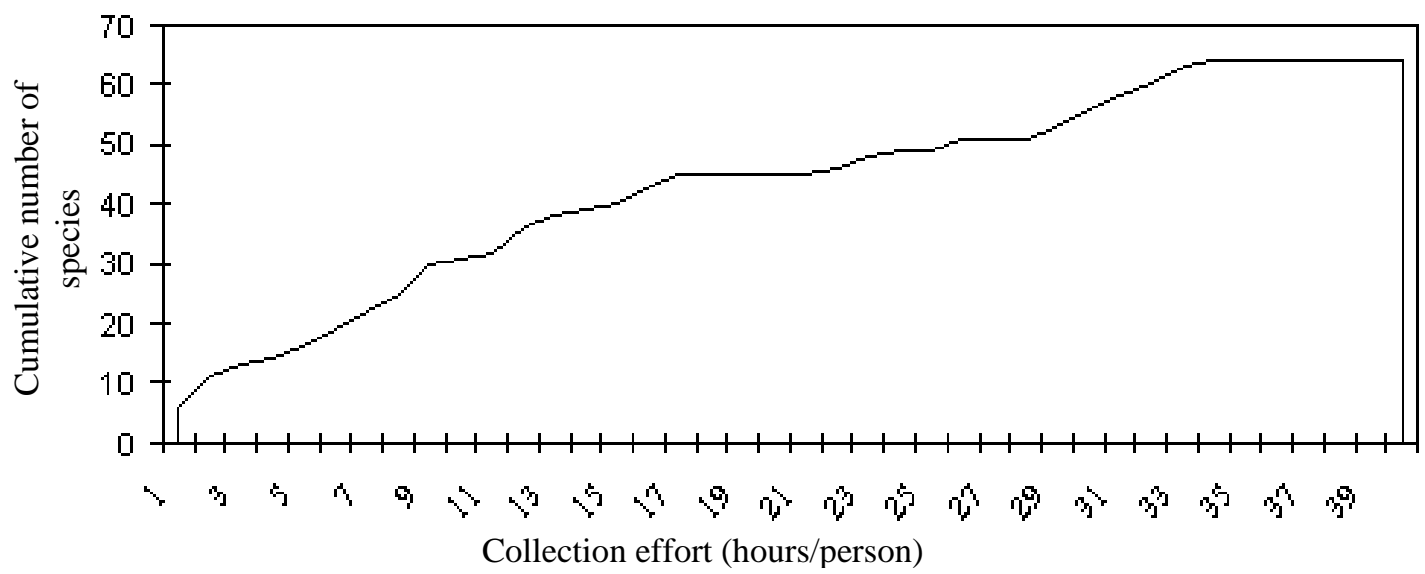

Figure 3. Species accumulation curve for bees at the Knuckles Forest Reserve.

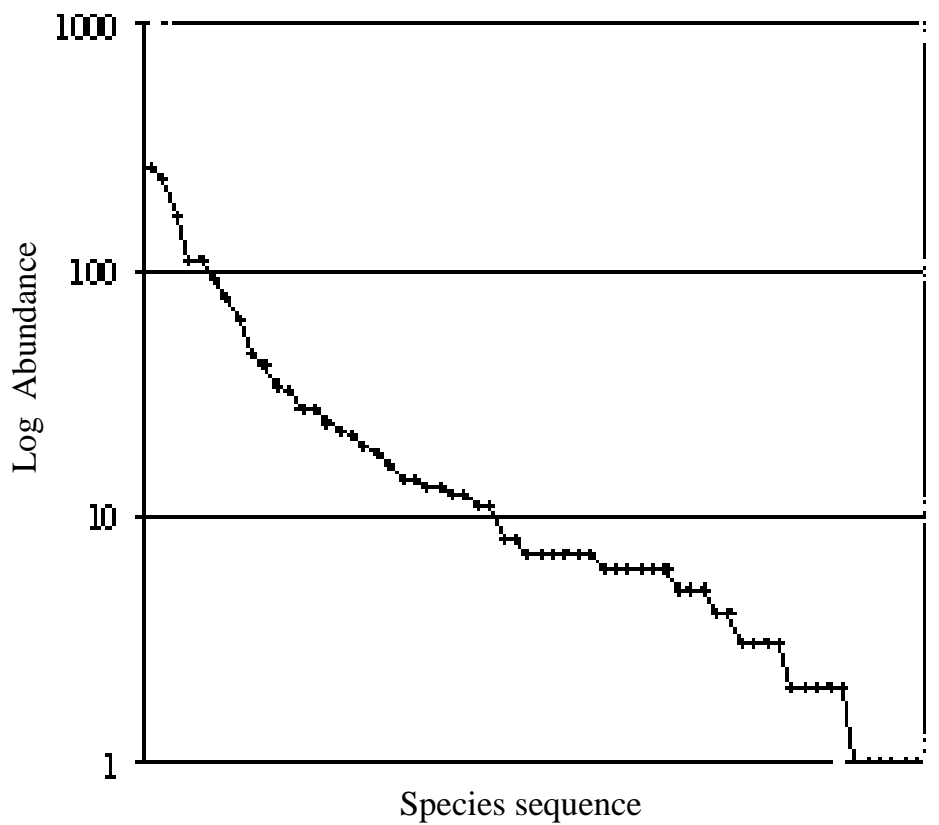

Figure 4. Plot of bee species abundance (log) against species sequence for the Knuckles Forest Reserve.

\section{DISCUSSION}

In the Knuckles forest reserve where 5 habitats are located at different altitudes ranging from 150-1350 m, a reduction in bee diversity was observed with increase in elevation. At lower elevation, where the highest bee species diversity was recorded, high temperature and dry weather conditions are prevalent for most months of the year. These climatic conditions result in long 
periods of flowering in herbaceous plants that is conducive to foraging and nesting in bees. Furthermore, at lower elevations the complexity in habitats due to diverse land use patterns creates additional nesting grounds where especially the stem nesting bees are abundant. Species of the genus Ceratina excavate their nests in small dead stems having central pith. Xylocopa collaris nested in fallen tree trunks in cultivated home gardens. Megachile species were also well represented at lower elevations where they nested in dead tree trunks.

In contrast at high elevations (1065-1350 m) with the area frequently covered with mist accompanied by low temperatures, the diversity of flowering herbaceous plants are low and the flowering periods are short. These conditions may have resulted in a low bee species composition and diversity at high elevations.

Furthermore, a distinct pattern was observed with respect to the species and genera of bees confined to a particular elevation representing a specific vegetation type. A grater number of species and genera were confined to lower elevations and are sustained by the diverse flora at lower altitudes. Most of the bee species at lower latitudes are common and widespread and are not endangered. In contrast, to the highest elevation, four of the bee species were confined. These four species; Lasioglossum (Sudila) alphenum, L.(Sudila) aulacophorum, L. (Sudila) bidentatun and L. (Evylaeus) carnifrons are of particular importance being endemic to Sri Lanka (Sakagami, et al, 1996). In addition, Sudila and Evylaeus are subgenera endemic to higher altitudes of the country. Hence, they are very important in maintaining the montane and submontane vegetation especially in the forest habitats and vise versa. They can be vulnerable to weather changes that may occur at higher altitudes due to global effects as the bees are sustained by seasonal flowering species in the montane and submontane forest habitats.

However, a few species ranged across the entire elevation gradients. Thus, the common honeybee Apis cerana frequented all the study sites throughout the year. Of the remaining three honeybees, A. dorsata and Trigona iridipennis were significantly absent in sites where cardamom was grown. A study carried out on pollination ecology of cardamom (Sinu and Shivanna, 2007) reported the presence of $A$. cerana and Amegilla spp. in the cardamom growing belt in the Western Ghats of India. The absence of the dwarf honey bee, A. florae, at higher elevations is significant, being limited to the lower elevations (150 - $450 \mathrm{~m})$ most likely due to climatic conditions rather than habitat availability.

The presence of a point endemic bee species was evident form the study. From the lowest elevation, a previously unrecorded Trigona sp. was collected and its identity is yet to be confirmed. According to previous studies, only a single species of Trigona; Trigona iridipennis is known to occur in Sri Lanka. The suspected species is likely to be a point endemic being recorded only from this site so far (Karunaratne, Edirisinghe and Pauly, 2005; Karunaratne, 2004).

The seasonal phenology of bees though not very marked, reflects the climatic variability and availability of host plants along the altitudinal gradient ensuing their presence and absence. Dry periods were experienced in May- July and are associated with strong winds. It is likely that these weather factors have contributed to the low number of bee species recorded during this period. In contrast certain bee species; Trigona sp. 1, Amegilla niveocincta, Coelioxys sp. 5 and Braunsapis sp. 1 were recorded only during the dry period and these species are also rare considering the short dry spell prevalent in the Knuckles range.

The focus on bee diversity in this mountainous forest range with numerous human activities enhances our understanding of how vegetation and land use pattern as influenced by altitude affect tropical bee communities.

\section{ACKNOWLEDGEMENTS}

This study which forms a part of a wider survey of bees in the island was funded by the National Science Foundation (NSF) of Sri Lanka. Authors are grateful to Dr. A. Pauly (Institut royal des Sciences naturelles de Belgique) Dr. S.W.T. Batra (formerly of the USDA) and Dr. B.B. Norden (formerly of the Smithsonian Institution, Washington) for confirming the identity of certain bee species. Field assistance provided by Mr. S. Chandrasekara and Mr. N. Ratnayake is greatly acknowledged.

\section{REFERENCES}

Baker, D. B. (1996). Notes on some palearctic and oriental Systropha, with descriptions of new 
species and a key to the species (Hymenoptera: Apoidea: Halictidae). Journal of Natural History 30: $1527-1547$.

Bambaradeniya C. N. B. and Ekanayake S. P. (2003). A guide to the biodiversity of Knuckles Forest Region, International Union for Conservation of Nature and Natural Resources, Sri Lanka. Dasis Printers (PVT) Ltd.

Bingham, C. T. (1897). The Fauna of British India including Ceylon and Burma, Hymenoptera Vol. 1, Wasps and Bees. Taylor and Francis. London. Pp. 577.

Karunaratne, W. A. I. P. (2004). Taxonomy and Ecology of bees in selected areas of Sri Lanka. Ph.D. Thesis. Postgraduate Institute of Science. University of Peradeniya. Pp. 343.

Magurran, A. E. (1988). Ecological Diversity and Its Measurements Croom Helm, London.

Michener, C. D. (2000). The Bees of the World, Baltimore, Maryland, USA: Johns Hopkin University Press. Pp 913.

Sakagami, S. F. (1978). Tetragonula stingless bees of the Continental Asia and Sri Lanka (Hymenoptera, Apidae), Journal of the Faculty of Science, Hokkaido University, Series VI, Zoology 21 (2): 165-247.
Sakagami, S. F. (1991). The halictid bees of Sri Lanka and the vicinity. II. Nesohalictus (Hymenoptera: Halictidae). Zoological Science 8: 169-178

Sakagami, S. F. and Ebmer, P. A. (1987). Taxonomic notes on Oriental halictine bees of the genus Halictus (Subgen. Seladonia) (Hymenoptera Apoidea), Linzer biol. Beitr. 19 (2): Pp 301-357.

Sakagami, S. F., Ebmer, A. W. and Tadauchi, O. (1996). The Halictine bees of Sri Lanka and the vicinity. III. Sudila (Hymenoptera: Halictidae) Part 1 .Esakia 36: 143-189.

Sakagami SF, Ebmer A. W. and Tadauchi O. (1998). The Halictine bees of Sri Lanka and the vicinity. III. Sudila (Hymenoptera: Halictidae) Part 2. Esakia 38: 55-83.

Schwarz, H. F. (1990). Beitrag zur Kenntnis orientalischer Nomada Arten. Entomofauna Suppl, cited in Michener, C. D. (2000) Bees of the world Baltimore, Maryland, USA.

Vergara, C. H. \& Ayala, R. (2002). Diversity, Phenology and Biogeography of the bees (Hymenoptera: Apoidea) of Zapotitlan de las Salinas, Puebla, Mexico, Journal of the Kansas Entomological Society 75 (1): 16-30. 
Appendix 1. Bees recorded form the 5 study locations (Nos. recorded in 41 h of collecting).

\begin{tabular}{|c|c|c|c|c|c|}
\hline \multirow[b]{2}{*}{ Bee family (Genera, Species) } & \multirow{2}{*}{\begin{tabular}{l}
\multicolumn{1}{c}{ Montane } \\
Natural \\
Forest \\
$(1350 \mathrm{~m})$
\end{tabular}} & \multicolumn{2}{|c|}{ Submontane } & \multicolumn{2}{|c|}{ Semi-evergreen } \\
\hline & & $\begin{array}{l}\text { Cardamom } \\
(1065 \mathrm{~m})\end{array}$ & $\begin{array}{l}\text { Pathana } \\
\text { Grassland } \\
(840 \mathrm{~m})\end{array}$ & $\begin{array}{l}\text { Cultivated } \\
\text { Home gar. } \\
(455 \mathrm{~m})\end{array}$ & $\begin{array}{l}\text { Paddy } \\
\text { fields etc. } \\
(150 \mathrm{~m}) \\
\end{array}$ \\
\hline APIDAE $(9,30)$ & & & & & \\
\hline Apis cerana & 32 & 36 & 30 & 51 & 35 \\
\hline Apis dorsata & 11 & & 2 & 6 & 3 \\
\hline Apis florea & & & & 4 & 2 \\
\hline Trigona iridipennis & 3 & & 6 & 7 & 18 \\
\hline Trigona sp. 1 & & & & & 12 \\
\hline Amegilla niveocincta & & & & 1 & 1 \\
\hline Amegilla comberi & & & 1 & 2 & 1 \\
\hline Amegilla puttalama & & & & & 8 \\
\hline Amegilla scintillans & & & & 19 & 5 \\
\hline Amegilla sp.3 & & & & 4 & 2 \\
\hline Amegilla subinsularis & & 27 & & & \\
\hline Braunsapis mixta & & & & 8 & 3 \\
\hline Braunsapis sp. 1 & 7 & & 4 & 21 & 14 \\
\hline Braunsapis sp. 2 & & & & & 16 \\
\hline Ceratina binghami & & & 19 & 93 & 124 \\
\hline Ceratina hieroglyphica & 13 & & 35 & 89 & 127 \\
\hline Ceratina smaragdula & & & & 3 & 24 \\
\hline Ceratina sp. 4 & & & & 52 & 26 \\
\hline Ceratina sp. 5 & & & & 7 & \\
\hline Nomada priscilla & 2 & & & & \\
\hline Nomada sp. 1 & & & 4 & & \\
\hline Tetralonia sp. 1 & & & 6 & & \\
\hline Thyreus ceylonicus & & & & 13 & 6 \\
\hline Thyreus histrio & & & & 6 & 1 \\
\hline Thyreus insignis & & & 7 & & \\
\hline Thyreus takaonis & & & & 8 & 5 \\
\hline Xylocopa amethystina & & & & & 3 \\
\hline Xylocopa collaris & & & 3 & 15 & \\
\hline Xylocopa ruficornis & & & 5 & 2 & \\
\hline Xylocopa tenuiscapa & & & 2 & 7 & 3 \\
\hline HALICTIDAE $(11,20)$ & & & & & \\
\hline Austronomia notiomorpha & & & & 4 & 2 \\
\hline Ceylalictus (Ceylalictus) sp.4 & & & & & 1 \\
\hline Gnathonomia nasicana & & & & & 6 \\
\hline Gnathonomia sp. & & & & & 5 \\
\hline Halictus lucidipennis & & & & 87 & 21 \\
\hline Hoplonomia westwoodi & & & & 21 & 11 \\
\hline Lasioglossum amblypygus & & & & 11 & 3 \\
\hline Lasioglossum (Evylaeus) carnifrons & 55 & & 7 & & \\
\hline Lasioglossum (Sudila) alphenum & 92 & & 16 & & \\
\hline Lasioglossum(Sudila)aulacophorum & 1 & 2 & & & \\
\hline Lasioglossum (Sudila) bidendatum & 2 & & & & \\
\hline Lasioglossum (Ctenonomia) sp. 5 & & & & 1 & 1 \\
\hline
\end{tabular}


Cont'd

Lasioglossum (Ctenonomia) sp. 4 Leuconomia sp.

Nomia crassipes

Pachynomia sp.

Patellapis (Pachyhalictus) sp. 3

Patellapis kaluterae

Pseudapis oxybeloides

Systropha tropicalis

MEGACHILIDAE $(5,12)$

Coelioxys capitata

Coelioxys sp. 5

Euaspis carbonaria

Euaspis sp. 1

Heriades binghami

Lithurgus atratus

Megachile hera

Megachile nana

Megachile sp. 2

Megachile umbripennis

Megachile vestita

Megachile vigilans

Total bees collected at each site (1694) 